\title{
Exports and Competitiveness of Indonesian Plywood
}

\author{
Indraswari Puruwita \\ Politeknik Statistika STIS \\ Jakarta, Indonesia \\ 15.8665@stis.ac.id
}

\author{
Siskarossa Ika Oktora \\ Politeknik Statistika STIS \\ Jakarta, Indonesia \\ siskarossa@stis.ac.id
}

\begin{abstract}
Indonesia is the top ten countries with the largest forest area in the world and has the potential to become the largest forest products exporter in the world. Wood and articles of wood are the only forest product commodities that are included in the ten export commodities with the largest share of the forest product in 2017, reaching 34\%. Plywood provides the largest share of wood and articles of wood, with $42 \%$ in 2017. Since 2005, Indonesia is no longer a major exporter of world plywood, and the export volume tends to decline until 2017. This study aims to analyze the exports and competitiveness of Indonesian plywood to three major trading partners (Japan, South Korea, and the United States) over the period 2000 to 2017. The method used is the Common Effect Panel Model with cross-section weighted. Based on the results, it can be concluded that REER, RCA, and trade openness affect the Indonesian plywood export significantly. The policy recommendation is to enhance partnerships between exporters and timber farmers (especially those with limited capital) to increase production. As well as increasingly tightening the Timber Verification and Legality System (SVLK) so that importers do not doubt the quality of Indonesian plywood.
\end{abstract}

Keywords-Export, Plywood, Common Effect Model with Cross-sectional weights

\section{INTRODUCTION}

Indonesia has a lot of natural resources. One of those is the forests, which makes Indonesia become one of the top ten countries with the largest forest in the world [1]. Based on UU No. 41 (1999), the forest has three kinds of functions: conservative function, protective function, and productive function. This productive function pushes Indonesia's potential to become the largest exporter in the world [2]. There are four forest product commodities that Indonesia produces and trade by two digits HS classification: wood, articles of wood, pulp, paper, and furniture. Wood and articles of wood are the only forest product commodities that are included in the ten export commodities with the largest share of the forest product in 2017, reaching 34\%. Plywood (HS 4412) provides the largest share of wood and articles of wood, reaching $42 \%$ in 2017.

Indonesia is one of the top five plywood exporters in the world and becomes the market leader in 2000-2004. After 2004, Indonesia is no longer become the market leader because plywood export value tends to decrease until 2009 while the other top five exporters increased. Therefore, Indonesia's position was replaced with China, while
Indonesia was in the third rank. In 2009, Indonesia's government was applying for SVLK (Timber Verification and Legality System), which was supposed to track and label the legal timbers [3]. The system indicated a good impact on Indonesian plywood export value, which increases after Indonesia applied it. However, Indonesian plywood export value was declining from 2015 to 2017 [4]. If this condition still exists, it can cause Indonesia to lose its potential in the international plywood market.

In 2017, international plywood demand reached 13 billion USD, and the top five importers are USA, South Korea, Japan, Germany, and England. Three of them are Indonesia's main plywood importers in 2017. Based on those facts, the study aims to analyze the exports and competitiveness of Indonesian plywood is needed.

\section{MATERIAL AND METHODS}

\section{A. Theories and Data}

The variables that affect an export are consumer tastes, price's goods, exchange rate, consumer income, transportation costs, and policies [5]. The driving factor of international trade is as an effort to get the goods cannot be produced by and to expand their market [6]. Openness also affects to country's international trade [7].

Indonesian plywood export volume can be affected significantly by the changes of plywood product, real price, real GDP, the real exchange rate of the trading partner, and SVLK policy [8]. Indonesian plywood export to Japan in the period 1980-2010 affected by Indonesian plywood production, Japan income, Indonesian exchange rate, and dummy policies of the government [9]. Indonesian plywood export to trading partner also affected by real GDP of the involved country, trading partner CPI, dummy crisis, exchange rate, and distance [10]. Indonesian guppy export to the trading partner in the period 2000-2011 affected by the interaction of these two countries real GDP, openness, exchange rate, and the price itself [11].

This study aims to analyze the export and competitiveness of plywood to three major trading partners. The data used in this study consists of export volume $(\mathrm{kg})$, openness, and export and import value (to compute RCA) from UNComtrade; REER, and GDP from World Bank; and plywood production (ton) from FAO. Time unit of this study is from 2000 to 2017, with the cross-section unit is the three major trading partners (USA, Japan, and South Korea). 


\section{B. Method}

The methods used in this study are RCA (Revealed Comparative Advantage), EPD (Export Product Dynamics), and panel data regression. RCA method, introduced by Balasa in 1965, is used to analyze the comparative advantage of the country's commodity [12]. The country has a comparative advantage when the value of RCA is more than 1 . RCA can be computed by:

$$
R C A_{i t}=\frac{x_{i j t}}{x_{n j t}} / \frac{x_{\text {iwt }}}{X_{\text {mut }}}
$$

Where:

$X_{i j t}$ : Export value of $\mathrm{i}$ commodity from $\mathrm{j}$ country in period $\mathrm{t}$ at trading partner

$X_{n j t}$ : Export value all of the commodities from $\mathrm{j}$ country in period $\mathrm{t}$ at trading partner

$X_{\text {iwt }}$ : Export value of i commodity from the whole country in period $\mathrm{t}$ at trading partner

$X_{n w t}$ : Export value all of the commodities from the whole country in period $t$ at trading partner

EPD is the indicator of competitiveness that focuses on the condition or the market position of the exporter at the trading partner [12]. The $\mathrm{X}$-axis represents business strength (export share) while $\mathrm{Y}$-axis represents attractiveness (product share). The result will be categorized between rising star (positive $\mathrm{X}$-axis and $\mathrm{Y}$-axis), lost opportunity (positive $\mathrm{Y}$-axis but negative $\mathrm{X}$-axis), retreat (negative- $\mathrm{X}$ and $\mathrm{Y}$-axis), and falling star (positive $\mathrm{X}$-axis, but negative Y-axis).

$Y$ Axis $=\frac{\left(\Sigma_{t=1}^{T}\left(\frac{X_{i j k}}{W_{i k}}\right)_{t} \times 100 \%-\Sigma_{t=1}^{T}\left(\frac{X_{i j k}}{W_{i k}}\right)_{t-1} \times 100 \%\right)}{T}$

$X$ Axis $=\frac{\left(\sum_{t=1}^{T}\left(\frac{X_{j k}}{W_{k}}\right)_{t} \times 100 \%-\Sigma_{t=1}^{T}\left(\frac{X_{j k}}{W_{k}}\right)_{t-1} \times 100 \%\right)}{T}$

Where:

$X_{\text {ijk }}$ : Export value i commodity from country j to country $\mathrm{k}$

$W_{i k}$ : Export value i commodity from world to country $\mathrm{k}$

$X_{i k}:$ Export value from country $\mathrm{j}$ to country $\mathrm{k}$

$W_{k}$ : Export value from world to country $\mathrm{k}$

$\mathrm{T}$ : The period of analysis

The procedures that should be done in panel data regression are data stationarity tests, selection model, variance-covariance error structure matrix test, classical assumption test, and interpretation of regression coefficient. In the stationarity test, if the null hypothesis is rejected, it means the data is stationary. Selection model use: Chow test to choose model between CEM (Common Effect Model) and FEM (Fixed Effect Model); BP-LM test to choose model between CEM and REM (Random Effect Model); and Hausman test to choose model between FEM and REM.

If the selected model is CEM or FEM, then variancecovariance error structure matrix test using the LM test is needed. This test is used to test of homoscedasticity of error. The $\lambda_{L M}$ test is used to test the cross-sectional correlation. The model should be checked the classical assumption, which is: normality; non-autocorrelation; and nonmulticollinearity test. In normality test, if the null hypothesis does not reject, then the error is normally distributed. In non-autocorrelation test if the null hypothesis does not reject, so there is a non-autocorrelation problem in the model. Non-multicollinearity test use VIF, which VIF value is less than 10, there is non-multicollinearity between explanatory variables. Panel data regression for this study as following [13]:

$\ln (V E)_{\text {it }}=\beta_{0}+\beta_{1} \ln \left(\right.$ Prod $_{\text {it }}+\beta_{2} \ln (G D P)_{\text {it }}+$ $\beta_{4} \ln (R E E R)_{\text {it }}+\beta_{6} \ln \left(O_{\text {pen }}\right)_{\text {it }}+\beta_{7} \ln (R C A)_{\text {it }}+\varepsilon_{\text {it }}$

Where:

$V E_{\text {it }} \quad$ : Export volume of Indonesian plywood to i trading partner in $t$ period

$G D P_{\text {it }}$ : GDP i trading partner in t period

Prod $_{i t}$ : Plywood production i trading partner in t period

$R E E R_{\text {it }}$ : Real Effective Exchange Rate of i trading partner in $t$ period

Open $_{i t}$ : Openness of $\mathrm{i}$ trading partner in $\mathrm{t}$ period

$R C A_{i t}$ : Competitiveness of $\mathrm{i}$ trading partner in $\mathrm{t}$ period

$\varepsilon_{i t} \quad$ : error term

$i \quad$ : individual (trading partner)

$t \quad$ : period (from 2000-2017)

\section{RESULT AND DISCUSSION}

\section{A. Plywood Export Volume}

Based on Figure 1 and Figure 2, Indonesian plywood export volume to the three main importers fluctuated. In 2002 to 2009, export volume tended to decrease. It coincided with the increasing awareness of the importers regarding illegal logging.

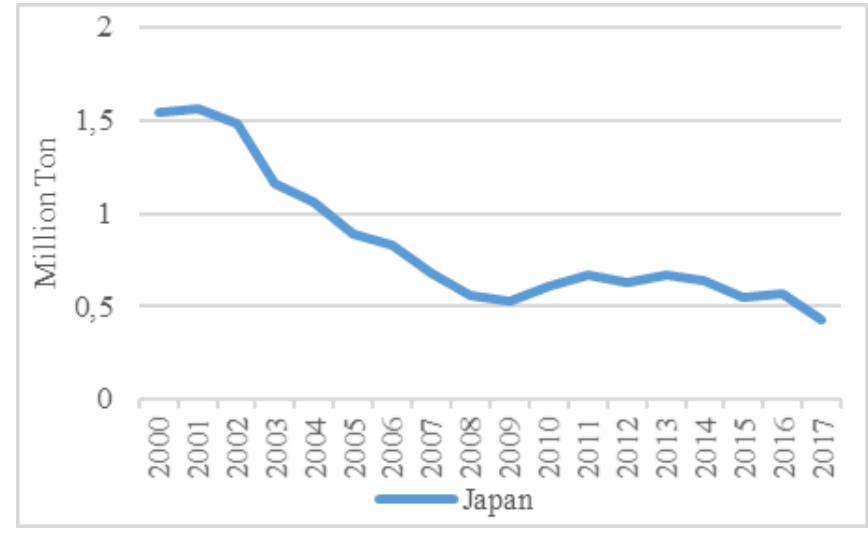

Source: UNComtrade

Fig 1. Indonesian plywood export volume to Japan in 2000-2017 




Source: UNComtrade

Fig 2. Indonesian plywood export volume to South Korea and the USA in 2000-2017

Indonesia had decided to be involved in eradicating illegal logging since 2001 [14]. Indonesia and Japan have been collaborating to eliminate illegal logging since 2000 [15]. It allegedly makes the export decrease Indonesia to Japan is more than other countries trading partner. After 2009, when the enforcement of SVLK policy, the export volume of plywood was increased. However, it was decreased in 2017 in conformity with the policy of Indonesian Trade Minister No. 84/M-DAG/PER/12/2016 about the policy of export product which is confined for some forest product, including plywood.

\section{B. Competitiveness}

Based on Figure 3 and Figure 4, RCA has a similar pattern to the plywood export volume to each destination country. There is a positive relationship between these two variables. It showed by the decrease of the RCA confirmed with the decrease of its export volume.

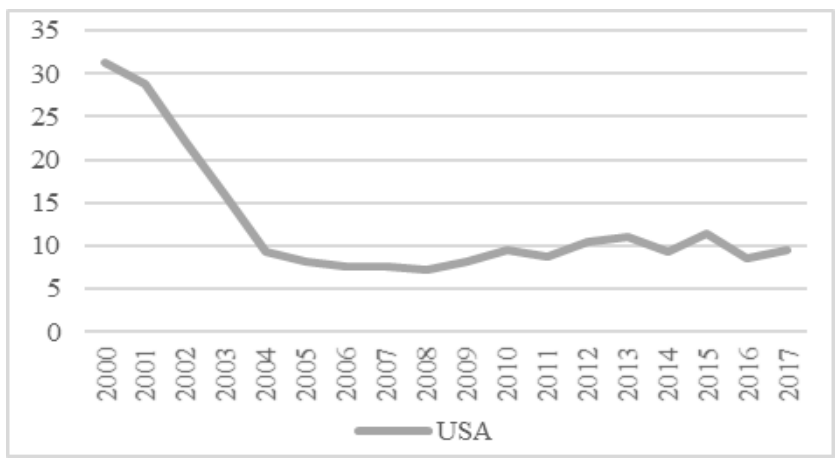

Source: UNComtrade (computed)

Fig 3. Indonesian Plywood RCA to the USA in 2000-2017

RCA in the USA was the highest of the others. However, it tends to decrease. The USA plywood import increased from 2000 to 2004 in the other trading partners, especially Brazil (reached 0,4 billion USD) and Canada (reached 0,2 billion USD). During this period Indonesian plywood export decreased, but this condition also existed in other exporters, so that Indonesian plywood RCA to the USA did not affect.



Source: UNComtrade (computed)

Fig 4. Indonesian plywood RCA to Japan and South Korea in 2000-2017

Besides, RCA of South Korea and Japan fluctuated. It is allegedly caused by the decreasing of their trust of the Indonesian plywood legality status. Since 2004, the importers more concerned about the importance of eradicating illegal logging. The export volume to South Korea and Japan increased after the SVLK policy applied in 2009. During this period, Japan and Indonesia also collaborate to eradicate illegal logging. Nevertheless, SVLK does not affect the USA. The USA still imports more plywood from Canada and Brazil.

All of the RCA values is more than one since 2000. It shows that Indonesia has a comparative advantage in producing and exporting plywood to those countries. But specifically using EPD method, the position of the Indonesian plywood competitiveness to the three exporter countries does not afford a good result.



Fig 5. Indonesian Plywood Competitiveness with EPD Method, 2000-2017

In Japan and South Korea, Indonesia position was in the retreat position. It means that the plywood product is not still in demand anymore. It showed by the decrease of export volume to those countries. Competitiveness of Indonesian plywood in the USA was in falling star position. This position shows that Indonesian plywood is still in demand, although the share of the product does not show good progress. 


\section{Determinants Indonesian Plywood Export to the Trading Partner}

For panel data regression analysis, stationarity data check is needed to avoid the spurious regression.

TABLE I. STATIONARITY TEST

\begin{tabular}{|c|c|c|c|c|}
\hline \multirow{2}{*}{ Variable } & \multicolumn{2}{|c|}{ Data Level } & \multicolumn{2}{c|}{ First Difference } \\
\cline { 2 - 5 } & $p$-value & Decision & $p$-value & Decision \\
\hline LnVE & 0.8299 & $\begin{array}{c}\text { Not } \\
\text { Stasionary }\end{array}$ & 0.0014 & Stasionary \\
\hline LnProd & 0.5760 & $\begin{array}{c}\text { Not } \\
\text { Stasionary }\end{array}$ & 0.0083 & Stasionary \\
\hline LnGDP & 0.2507 & $\begin{array}{c}\text { Not } \\
\text { Stasionary }\end{array}$ & 0.0005 & Stasionary \\
\hline LnREER & 0.6310 & $\begin{array}{c}\text { Not } \\
\text { Stasionary }\end{array}$ & 0.0041 & Stasionary \\
\hline LnOpen & 0.4780 & $\begin{array}{c}\text { Not } \\
\text { Stasionary }\end{array}$ & 0.0001 & Stasionary \\
\hline LnRCA & 0.8831 & $\begin{array}{c}\text { Not } \\
\text { Stasionary }\end{array}$ & 0.0012 & Stasionary \\
\hline
\end{tabular}

The test from table 1 shows that these six variables used in this study are stationary in first difference form with $\alpha=$ $10 \%$.

From the Chow test results the p-value 0.4915 , so the null hypothesis is not rejected. It means the Common Effect Model (CEM) is better than the Fixed Effect Model (FEM). The BP-LM test affords p-value 0.4031, and the result does not reject the null hypothesis. It can be concluded that CEM is better than the Random Effect Model (REM).

For the next step, the homogeneous of variancecovariance error matrix test is needed. The LM test result shows the value of the statistic test is 18.9653 while $X_{0.122}^{2}$ is 4.605 , and the null hypothesis is rejected. It means that there is heteroscedasticity of variance-covariance error matrix in the model and (the $\lambda_{L M}$ test) is needed. The result shows the value of the statistic test is 0.5404 while $X_{0.13}^{2}$ is 6.251 . Because the result does not reject the null hypothesis, so there is no cross-section correlation. Therefore, the right model to be used is CEM with cross-section weights [16].

The estimation regression form is:



*: significant at $\alpha=10 \%$

This model has fulfilled the assumptions that are needed: normality, non-autocorrelation, and non-multicollinearity. Normality test using Jarque Berra test affords p-value 0.7888 , which concludes that the distribution of error is normal. Non-autocorrelation with run test method provides p-value 0.890 , which shows that there is no autocorrelation in this model. Non-multicollinearity test with VIF indicates that there are no variables which have a VIF value more than 10 . It means that there is no multicollinearity between the independent variables.
Based on the estimation, it can be concluded that the REER, openness, and RCA affected Indonesian plywood export volume significantly. Plywood productions of the three importers do not affect Indonesian plywood export volume significantly. This result is in line with the finding of Rahmi's research, where the increase of production insignificantly affected the volume import [17]. That will happen when the increase in consumption is more than the increase in production so that the country will remain to import.

Real GDP of the trading partner has a positive effect on Indonesian plywood export volume. This result is in line with a theory, where the import would have a positive relationship with the income of itself [6]. But this effect is insignificant. It is in line with the result of Marbun's research, which found that the GDP of trading partner will positively affect insignificant because the country will focus on the stability import quota of the Indonesian plywood [18].

REER affects positively significant to Indonesian plywood export volume. The coefficient concludes that one percent changes of the REER growth will be followed by 0.4086 percent changes of the plywood export volume growth The appreciation of exchange rate would affect an increase of export because the price is relatively low [5]. It is also in line with the result of Rizqi's research that REER of trading partner affects positively significant to Indonesian plywood export volume to the trading partner [8].

Based on the result of the estimation model, the openness of the trading partner affects negatively significant to Indonesian plywood export volume. The coefficient concludes that one percent changes of the openness growth will be followed by 0.447 percent changes in the growth of plywood export volume. The result is in line with the Adam Smith's theory, which openness would drive the competitiveness, increasing production, value-added, and the lower price, so society will choose to consume domestic product due to the price [19]

The estimation model shows that the RCA affects Indonesian plywood export volume positively significant. The coefficient concludes that one percent changes of the RCA growth will be followed by 0.4328 percent changes in the growth of plywood export volume. The result is in line with the result of Lukmana's research where the competitiveness using RCA affect positively significant to Indonesian plywood export volume to the trading partner. It means the increasing of RCA will be followed by an increase in export [20].

\section{CONCLUSION AND RECOMMENDATION}

Based on the results, there are some conclusions. First, the trend of Indonesian plywood export volume fluctuated. This fluctuation is in line with the fluctuation of plywood production. Second, Indonesian plywood competitiveness that computes with the RCA method was unstable and in line with their export volume. The position of Indonesian plywood competitiveness to Japan and South Korea is in retreat position while the USA is in falling star position. Third, variables that significantly affect the Indonesian plywood export volume to three main importers are REER, the openness of trading partner, and RCA. 
Therefore, some recommendations are made to give. First, increase the raw material of plywood with paying attention of the management and maintenance of the forest and improve the partnership between the exporter and the timber farmer, especially for the limited capital for the means of increasing the production of Indonesian plywood. Second, improve the technology used in the process of making plywood to increase the value-added, quality itself and the competitiveness, and establish cooperation between the country in the international market.

\section{REFERENCES}

[1] Land in 2015," accessed on December $15^{\text {th }} 2019$ from http://fao.org/faostat/en/\#data/FO/.

[2] Presiden RI, "Undang-undang Republik Indonesia Nomor 41 Tahun 1999 Tentang Kehutanan," accessed on November $7^{\text {th }} 2019$ from http://lpp.dephut.go.id/.

[3] SILK, "Tentang SVLK, APa dan Bagaimana SVLK," accessed on May $17^{\text {th }} 2019$ from http://silk.dephut.go.id/.

[4] UN Comtrade, "UN Comtrade Database," accessed on December $15^{\text {th }}$ 2019 from http://comtrade.un.org/data/.

[5] S. Sukirno, Teori Pengantar Makroekonomi Edisi Ketiga, Jakarta: PT Raja Grafindo Pertama, 2004.

[6] T. Tambunan, "Globalisasi dan Perdagangan Internasional," Bogor: Ghalia Indonesia, 2004.

[7] D. Iswanto, "Faktor-faktor yang Mempengaruhi Ekspor Kayu Lapis Indonesia ke Jepang," Jurnal Ekonomi Pembangunan: FE Universitas Negeri Padang, 2013

[8] A. Rizqi, "Pengaruh Kebijakan Sistem Verifikasi Legalitas Kayu Terhadap Ekspor Kayu Lapis Indonesia Tahun 2009-2016," Skripsi, Jakarta: Politeknik Statistika STIS, 2018. N. G. Mankiw, Pengantar Ekonomi Jilid 2," Jakarta: Penerbit Erlangga, 2003.

[9] K. R. Sari and Widyastutik, "Faktor yang Mempengaruhi dan Estimasi Tarif Ekuivalen NTBs Ekspor Kayu Lapis Indonesia," Bogor: Institut Pertanian Bogor, 2015.
[10] N. T. Prastomo, "Keunggulan Komparatif dan faktor-faktor yang Mempengaruhi Ekspor Ikan Hias Indonesia ke Sepuluh Negara Tujuan Utama Ekspor Periode 2000-2011," Skripsi, Yogyakarta: Sekolah Tinggi Ilmu Statistik, 2013.

[11] S. T. V. Pandiangan, I. Narita, dan H. L. Kinanti, "Strategi Peningkatan Daya Saing Ekspor Industri Alas Kaki Olahraga Indonesia dengan Metode Analisis Porter Diamond," Skripsi, Yogyakarta: Universitas Gadjah Mada, 2018.

[12] A. M. Hasibuan, R. Nurmalina, and A. Wahyudi, "Analisis Kinerja dan Daya Saing Perdagangan Biji Kakao dan Produk Kakao Olahan Indonesia di Pasar Internasional,” Buletin RISTRI Vol 3(1), 2012.

[13] B. H. Batalgi, Econometric Analysis of Panel Data Third Edition, England: John Willey \& Sons, Ltd, 2005.

[14] Sanace Creek Associates. LLC, Wood Resources Internationnal. LLC, "Illegal Logging and Global Wood Market: The Competitive Impacts on the U.S. Wood Product Industry," American Forest and Paper Association, 2004.

[15] L. F. Casero, "Laws, Regulations and Policy Measures Governing Forest Product," in press.

[16] M. Ekananda, "Analisis Ekonometrika Data Panel Edisi Kedua," Jakarta: Mitra Wacana Media, 2016.

[17] F. K. Rahmi, "Faktor-faktor yang mempengaruhi Impor Beras Indonesia Tahun 1999-2013," Skripsi, Yogyakarta: Universitas Islam Indonesia, 2016.

[18] L. Marbun, "Pengaruh Produksi, Kurs dan GDP terhadap ekspor Kayu Lapis," Economics Development Journal, 2015.

[19] W. Herawati. "Analisis Pengaruh Keterbukan Ekonomi terhadap Pertumbuhan Ekonomi di Indonesia Tahun 1980-2012," Skripsi, Yogyakarta: Universitas Negeri Yogyakarta, 2016.

[20] H. Lukmana, "Analisis Daya Saing dan Faktor-faktor yang Mempengaruhi Ekspor Tekstil Indonesia ke Pasar Korea Selatan Tahun 1992-2016," Skripsi, Surakarta: Universitas Muhammadiyah Surakarta, 2018. 